\title{
Assessing Viral Hepatitis B and C Seroprevalence among Two at Risk Populations in Taraba State: A Seroprevalence Study
}

\author{
Rimande Ubandoma Joel ${ }^{2}$, Obed Tiwah John ${ }^{1,3^{*}}$, Tomen Egbe $\mathrm{Agu}^{2}$, Samson Ozulonye Ogbuagada ${ }^{4}$, Nasiru Yakubu ${ }^{3}$ \\ Abdulhafiz Lamiya ${ }^{1,3}$ \\ ${ }^{I}$ Department of Research, Center For Initiative and Development (CFID), Taraba \\ ${ }^{2}$ Department of Public Health, Taraba State University, Jalingo, Nigeria \\ ${ }^{3}$ Department of Statistics \& Operations Research, Modibbo Adama University Yola, Nigeria \\ ${ }^{4}$ Federal University, Wukari, Nigeria \\ *Corresponding author
}

\begin{abstract}
Viral hepatitis is the inflammation of the liver caused by some hepatotropic viruses that indiscriminately infect all populations with certain sub-populations being more at risk/vulnerable to the infection. The highest burden of the infection is seen in sub-Saharan Africa with Nigeria belonging to the highly endemic countries with Taraba state having the highest burden in the country. It is undisputable that data regarding the prevalence of this infection is key in the prevention, management and control of epidemic by responsible bodies and authorities globally. However, data regarding viral hepatitis among at risk population remain scanty and continuous to prevail despite the endemicity of the disease in the region. It is against this background that this study sought to determine the prevalence of the disease among two at risk populations in Jalingo-Taraba State who accessed testing services at center for initiative and development Taraba state- Nigeria. A total of 397 individuals comprising of $\mathbf{1 6 0}$ health care workers and 237 people living with HIV were considered for the study. A total of 138 subjects were males while 259 were females within the age bracket of 8-80 years. Out of the total participants, forty-six 46/397(11.6\%) were positive for HBV out of which $9(2.27 \%)$ were HCW and $37(9.32 \%)$ were PLHIV. However, no statistically significant association was found between at-riskpopulation and HBV status. A total of 54/397(13.6\%) subjects were positive to $\mathrm{HCV}$ out of which $17(4.28 \%$ ) were $\mathrm{HCW}$ and 37(9.32\%) were PLHIV but no statistically significant association was found between at-risk population and $\mathrm{HCV}$ status of the subjects. A total of $5 / 397$ participants $(1.26 \%)$ were coinfected with viral hepatitis $B$ and $C$ out of which $(0(0 \%), 1(0.25 \%))$ were Males and females HCWs while $(0(0 \%), 4(1.01 \%))$ were males and females PLHIV respectively. The age group between 22-33 and 34-45 recorded $20(5 \%)$ each for $\mathrm{HBV}$ while the age group of $70+$ recorded $0(0 \%)$ prevalence for $\mathrm{HBV}$. The age group of 34-45 recoded the highest prevalence of $23(5.8 \%)$ for $\mathrm{HCV}$ infection while the age group of 58-69 recorded $0(0 \%)$ followed by $70+$ who recorded $2(0.5 \%)$. The findings of this study reported a high prevalence of viral hepatitis infection amongst at risk population and this is a clear indication that the ailment is posing serious threat to the health care system and the region at large. This calls for the employment of aggressive preventive and elimination measures so as to succeed in achieving vison 2030.
\end{abstract}

Key words: Viral hepatitis; health care workers; people living with HIV and co-infection

\section{INTRODUCTION}

$\mathrm{H}$ epatitis is a health condition characterized by inflammation of the liver cells commonly caused by viral infection which can either be acute or chronic, symptomatic or asymptomatic and can lead to liver damage. Further complications can arise from various causes such as heavy intake of alcohol, toxin ingestion and certain suppressive medical conditions [1]. Hepatitis B virus HBV and Hepatitis $\mathrm{C}$ virus $\mathrm{HCV}$ are public health problems worldwide and are among the main causes of liver cirrhosis and hepatocellular carcinoma [2]. In 2015, [3] estimated that there were 257 million people with chronic HBV infection and 71 million people with chronic HCV infection worldwide. [4] reported that these infections have reached endemic proportions in subSaharan Africa. According to 63rd World Health Assembly (WHA63.18), inadequate preventive and control measures, as well as lack of access to appropriate and affordable treatment, are responsible for the increased morbidity of viral hepatitis in developing countries such as sub-Saharan Africa [5]. WHO also estimated that in 2015, viral hepatitis led to 1.34 million deaths worldwide and chronic infections with hepatitis B virus (HBV) and hepatitis $\mathrm{C}$ virus (HCV) accounting for more than $90 \%$ of viral hepatitis mortality. Nigeria is one of the countries with the highest burden of viral hepatitis with a prevalence of $8.1 \%$ of Hepatitis $\mathrm{B}$ and $1.2 \%$ of Hepatitis C [6]. Hepatitis $B$ and $C$ viruses can be transmitted by exposure to contaminated blood or infected body secretions but can be transmitted through other situations such as percutaneous exposure (needle-sticks/ injection drug use; IDU) or body fluid contaminated with blood containing the virus, or invasive procedures such as phlebotomy, haemodialysis and surgery involving infected blood or instrument contaminated with these viruse [4]. Some people termed at risk population have higher chances of contracting this disease. Such population include people living with HIV (PLWH), health 
care workers (HCW), people who inject drugs (PWID), people with multiple sex partners, iatrogenic infection and children born to infected mothers [7]. However this ailment can be prevented among the at risk population through standard protocol of vaccination and other prophylactic measures [8]. The disease can also be treated or managed in infected individuals through comprehensive health education on blood borne pathogens and immunization for at risk population, antiviral drugs [9] and immunostimulatory therapy with alpha-interferon [5].

The importance of data in health management cannot be overemphasized. However, the paucity of data continues to prevail in developing countries Nigeria inclusive despite the challenge paused by this ailment in this countries. Nigeria is a viral hepatitis endemic country with a prevalence rate of $10 \%$ - 40\% for HBV and 4.7\% - 20\% for HCV [4] and Taraba state recording the highest prevalence in the country [9]. Despite this, there is still a high percentage of the at risk population that still have their status unknown and data of such population continues to remain un-uniform and scanty. It is against this background that this research aimed at investigating the sero-prevalence of viral hepatitis B and or C amongst at risk population so as to manage and reduce the endemicity of this ailment through re-strategizing and modification of management mechanisms.

\section{MATERIALS AND METHODS}

\section{Study region and population}

This was a cross-sectional descriptive study carried out at Center for Initiative and development (CFID) in Taraba State. The Hepatitis Counselling and Testing (HCT) unit of CFID is responsible for carrying out free testing and counselling of viral hepatitis in Taraba State with it's headquarters in Jalingo being the capital city of Taraba state. Its coordinates are $8^{0} 54^{\prime} \mathrm{N}$ and $11^{0} 22^{\prime} \mathrm{E}$ and have an estimated population of 118,000 people. The targeted population for this study included individual who are at risk with specific reference to People Living with Human Immuno-Deficiency Virus (PLHIV) and Health care workers (HCWs). These categories of population of at least 8 years of age and seeking medical care at CFID were eligible for the study. Three hundred and ninety seven subjects were enlisted for the study which took place at CFID in 2019.

\section{Determination of Sample Size}

Sample size determination was calculated using Cohcran's formular for determining sample size as given below:

$$
n=\frac{z^{2} p q}{e^{2}}
$$

$$
\begin{aligned}
& \text { Where } \mathrm{n}=\text { is the sample size } \\
& \mathrm{P} \quad=\text { is the estimated population proportion (0.16) } \\
& \mathrm{q}=1-\mathrm{p}(0.84) \\
& \text { e } \quad=\quad \text { is the desired level of precision }(0.05)
\end{aligned}
$$

therefore, $n=\frac{(1.96)^{2} \times 0.16 \times 0.84}{(0.05)^{2}}=207$

The estimated sample size (207) was increased to 397 to ensure adequate power for the study.

\section{Sample collection and analysis}

Prior to data collection, the investigators set out plans on how to go about data collection by engaging well trained and qualified Lab Technicians of HCT department CFID to facilitate blood sample collection and to ensure that common understanding on the tools is been observed. The data were facially validated by the researchers.

Hepatitis B and C register book was used to record variables under consideration such as HCWs, PLHIV, hepatitis B and or $\mathrm{C}$ virus statuses, Sex and age categories of the participants were also captured accordingly.

\section{Laboratory analysis and Screening}

The blood samples were collected while serum was used to screen for HBsAg and anti-HCV. A drop of the serum $(10 \mu)$ was dropped on the test strip following manufacturer's guidelines and instructions. Result was read and recorded 5 to 10 minutes in accordance with the stated instruction. In determining and recording the results, when two lines appears, this implies seropositive while only one line at the control region is an indication of sero-negative.

\section{Statistical analysis}

Statistical analyses were performed using SPSS verson 25, Microsoft excel 2016 and Minitab version 17. Data collected were extracted from Microsoft spread sheet and moved to statistical package for social science (SPSS) for cleaning and validation. Simple percentages were used to describe demographic variables while crosstabulations contingency tables, pie charts graphs and Chi-square test was used for further analysis. A p-value $<0.05$ was considered statistically significance.

\section{Limitation}

At risk population are quite enormous. However, this study was limited to two at-risk-populations (HCWs and PLHIV) out of numerous others.

\section{RESULTS}

Figure 1. Gender distribution of Participants

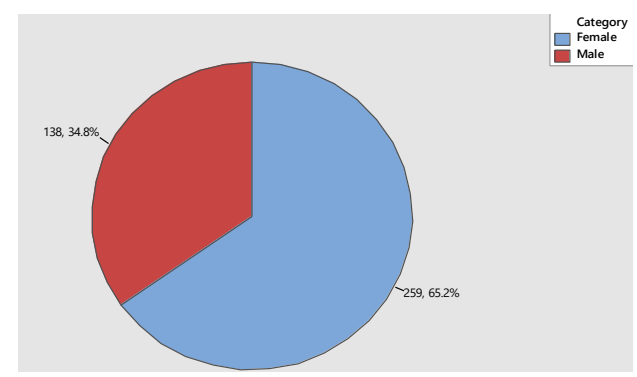

Figure 2. Pie Chart Showing Age Distribution of Participants in the study Area 


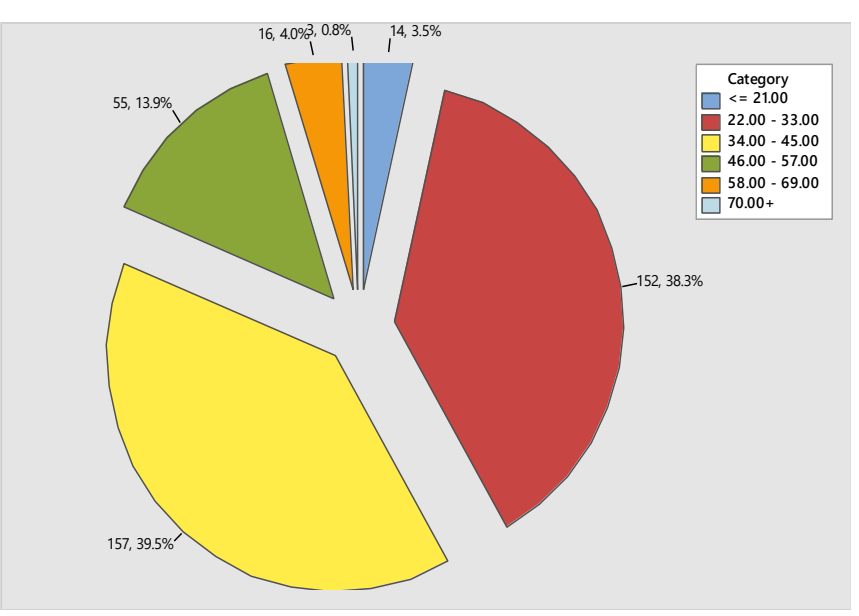

Figure 3. HBsAg Status of Participants

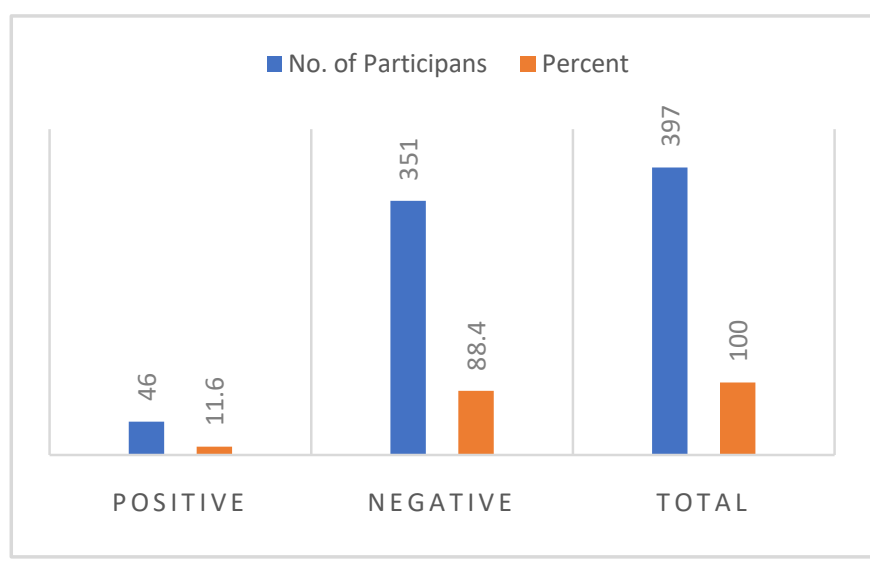

Figure 4. HCV Status of Participants

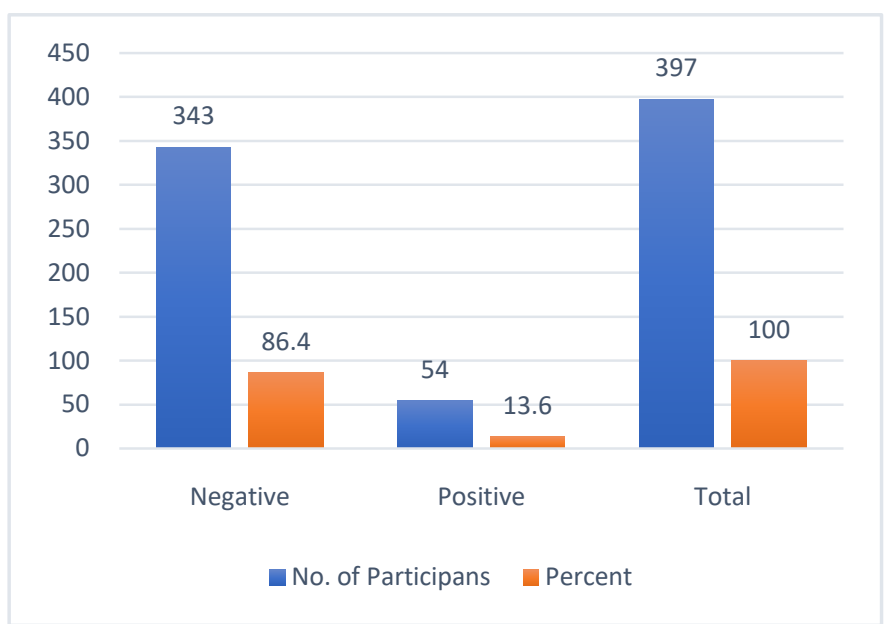

Table 1. Tabulated Statistics of at-risk Participants against HBsAg

\begin{tabular}{|c|c|c|c|c|c|}
\hline $\begin{array}{c}\text { VARIABLE } \\
\text { S }\end{array}$ & $\begin{array}{c}\text { NEGATIV } \\
\text { E }\end{array}$ & $\begin{array}{c}\text { POSITIV } \\
\text { E }\end{array}$ & TOTAL & $\begin{array}{c}\text { CHI- } \\
\text { SQ } \\
\text { VALU } \\
\text { E }\end{array}$ & $\begin{array}{c}\text { P- } \\
\text { valu } \\
\text { e }\end{array}$ \\
\hline HCWs & $\begin{array}{c}151 \\
(38.04 \%)\end{array}$ & $9(2.27 \%)$ & $\begin{array}{c}160(40.30 \\
\%\end{array}$ & 9.299 & 0.00 \\
\hline
\end{tabular}

\begin{tabular}{|c|c|c|c|c|c|}
\hline PLHIV & $\begin{array}{c}200(50.38 \\
\%)\end{array}$ & $37(9.32 \%)$ & $\begin{array}{c}237(59.70 \\
\%)\end{array}$ & & 2 \\
\cline { 1 - 4 } TOTAL & $\begin{array}{c}351(88.41 \\
\%)\end{array}$ & $\begin{array}{c}46(11.59 \\
\%)\end{array}$ & $397(100 \%)$ & & \\
\hline
\end{tabular}

Table 2. Tabulated Statistics of at-risk Participants against HCV

\begin{tabular}{|c|c|c|c|c|c|}
\hline $\begin{array}{c}\text { VARIABLE } \\
\text { S }\end{array}$ & $\begin{array}{c}\text { NEGATIV } \\
\text { E }\end{array}$ & $\begin{array}{c}\text { POSITIV } \\
\text { E }\end{array}$ & TOTAL & $\begin{array}{c}\text { CHI- } \\
\text { SQ } \\
\text { VALU } \\
\text { E }\end{array}$ & $\begin{array}{c}\text { P- } \\
\text { valu } \\
\text { e }\end{array}$ \\
\cline { 1 - 4 } HCWs & $\begin{array}{c}143 \\
(36.06 \%)\end{array}$ & $17(4.28 \%)$ & $\begin{array}{c}160(40.30 \\
\%)\end{array}$ & & \\
\cline { 1 - 3 } PLHIV & $\begin{array}{c}200(50.38 \\
\%)\end{array}$ & $37(9.32 \%)$ & $\begin{array}{c}237(59.70 \\
\%)\end{array}$ & \multirow{2}{*}{2.021} & 0.15 \\
TOTAL & $\begin{array}{c}351(86.40 \\
\%\end{array}$ & $\begin{array}{c}54(13.60 \\
\%)\end{array}$ & $397(100 \%)$ & & \\
\hline
\end{tabular}

Table 3. Tabulated Statistics of at-risk Participants against HBsAg and HCV

\begin{tabular}{|c|c|c|c|}
\hline VARIABLES & NEGATIVE & $\begin{array}{c}\text { POSITIVE(Co- } \\
\text { infection) }\end{array}$ & TOTAL \\
\hline HCWs & $\begin{array}{c}135 \\
(34.01 \%)\end{array}$ & $1(0.25 \%)$ & $160(40.30 \%)$ \\
\hline PLHIV & $167(42.07 \%)$ & $4(1.01 \%)$ & $237(59.70 \%)$ \\
\hline TOTAL & $302(76.07 \%)$ & $5(1.26 \%)$ & $397(100 \%)$ \\
\hline
\end{tabular}

Table 4. Tabulated Statistics of Participants Gender against HBsAg

\begin{tabular}{|c|c|c|c|c|c|}
\hline $\begin{array}{c}\text { VARIABLE } \\
\text { S }\end{array}$ & $\begin{array}{c}\text { NEGATIV } \\
\text { E }\end{array}$ & $\begin{array}{c}\text { POSITIV } \\
\text { E }\end{array}$ & TOTAL & $\begin{array}{c}\text { CHI- } \\
\text { SQ } \\
\text { VALU } \\
\text { E }\end{array}$ & $\begin{array}{c}\text { P- } \\
\text { valu } \\
\text { e }\end{array}$ \\
\cline { 1 - 4 } FEMALE & $\begin{array}{c}224 \\
(56.42 \%)\end{array}$ & $35(8.82 \%)$ & $\begin{array}{c}259(65.24 \\
\%)\end{array}$ & & \\
\cline { 1 - 3 } MALE & $\begin{array}{c}127(31.99 \\
\%)\end{array}$ & $11(2.77 \%)$ & $\begin{array}{c}138(34.76 \\
\%)\end{array}$ & \multirow{2}{*}{2.700} & 0.10 \\
TOTAL & $\begin{array}{c}351(88.41 \\
\%)\end{array}$ & $\begin{array}{c}46(11.59 \\
\%)\end{array}$ & $397(100 \%)$ & & \\
\hline
\end{tabular}

Table 5. Tabulated Statistics of Participants sex against HCV

\begin{tabular}{|c|c|c|c|c|c|}
\cline { 1 - 3 } $\begin{array}{c}\text { VARIABLE } \\
\text { S }\end{array}$ & $\begin{array}{c}\text { NEGATIV } \\
\mathrm{E}\end{array}$ & $\begin{array}{c}\text { POSITIV } \\
\mathrm{E}\end{array}$ & TOTAL & $\begin{array}{c}\text { CHI- } \\
\text { SQ } \\
\text { VALU } \\
\mathrm{E}\end{array}$ & $\begin{array}{c}\text { P- } \\
\text { valu } \\
\mathrm{e}\end{array}$ \\
\cline { 1 - 4 } FEMALE & $\begin{array}{c}220 \\
(55.42 \%)\end{array}$ & $39(9.82 \%)$ & $\begin{array}{c}259(65.24 \\
\%)\end{array}$ & & \\
\cline { 1 - 4 } MALE & $\begin{array}{c}123(31.99 \\
\%)\end{array}$ & $15(3.78 \%)$ & $\begin{array}{c}138(34.76 \\
\%)\end{array}$ & \multirow{2}{*}{1.344} & $\begin{array}{c}0.24 \\
6\end{array}$ \\
\cline { 1 - 4 } TOTAL & $\begin{array}{c}343(86.40 \\
\%)\end{array}$ & $\begin{array}{c}54(13.60 \\
\%)\end{array}$ & $397(100 \%)$ & & \\
\hline
\end{tabular}

Table 6. Tabulated Statistics of At-risk population, sex vs HBsAg and HCV Coinfection

\begin{tabular}{|c|c|c|c|c|}
\hline $\begin{array}{c}\text { VARIAB } \\
\text { LES }\end{array}$ & GENDER & $\begin{array}{c}\text { NEGATIV } \\
\text { E }\end{array}$ & $\begin{array}{c}\text { POSITIVE } \\
(\text { COINFECTI } \\
\text { ON })\end{array}$ & TOTAL \\
\hline \multirow{2}{*}{ HCWS } & FEMALE & $65(16.37 \%)$ & $1(0.25 \%)$ & $\begin{array}{c}76(19.1 \\
4 \%)\end{array}$ \\
\cline { 2 - 5 } & MALE & $70(17.63 \%)$ & $0(0.00 \%)$ & $\begin{array}{c}84(21.1 \\
6 \%)\end{array}$ \\
\hline PLHIV & FEMALE & $\begin{array}{c}125(31.49 \% \\
)\end{array}$ & $4(1.01 \%)$ & $\begin{array}{c}183(46 . \\
10 \%)\end{array}$ \\
\hline & MALE & $42(10.58 \%)$ & $0(0.00 \%)$ & $\begin{array}{c}54(13.6 \\
0 \%)\end{array}$ \\
\hline TOTAL & & $\begin{array}{c}302(76.07 \% \\
)\end{array}$ & $5(1.26 \%)$ & $\begin{array}{c}397(10 \\
0.00 \%)\end{array}$ \\
\hline
\end{tabular}


International Journal of Research and Innovation in Applied Science (IJRIAS) |Volume VI, Issue IX, September 2021|ISSN 2454-6194

Table 7. Tabulated Statistics of At-risk population, Age Range, HBsAg and HCV

\begin{tabular}{|c|c|c|c|c|}
\hline VARIABLES & AGE CATEGORIES & NEGATIVE & $\begin{array}{c}\text { POSITIVE } \\
\text { (Coinfection of } \\
\text { HBV\&HCV) }\end{array}$ & TOTAL \\
\hline \multirow{2}{*}{ HCWS } & $<=21$ & $5(1.259 \%)$ & $0(0.000 \%)$ & $6(1.511 \%)$ \\
\hline & $22-33$ & $46(11.587 \%)$ & $0(0.000 \%)$ & $58(14.610 \%)$ \\
\hline & $34-45$ & $52(13.098 \%)$ & $1(0.252 \%)$ & $58(14.610 \%)$ \\
\hline & $46-57$ & $25(6.297 \%)$ & $0(0.000 \%)$ & $28(7.053 \%)$ \\
\hline & $58-69$ & $6(1.511 \%)$ & $0(0.000 \%)$ & $7(1.763 \%)$ \\
\hline & 70 and above & $1(0.252 \%)$ & $0(0.000 \%)$ & $3(0.763 \%)$ \\
\hline \multirow[t]{6}{*}{ PLHIV } & $<=21$ & $5(1.259 \%)$ & $1(2.252 \%)$ & $8(2.015 \%)$ \\
\hline & $22-33$ & $68(17.128 \%)$ & $1(2.252 \%)$ & $94(23.678 \%)$ \\
\hline & $34-45$ & $65(16.373 \%)$ & $2(0.504 \%)$ & $99(24.937 \%)$ \\
\hline & $46-57$ & $20(5.038 \%)$ & $0(0.00 \%)$ & $27(6.801 \%)$ \\
\hline & $58-69$ & $9(2.267 \%)$ & $0(0.00 \%)$ & $9(2.267 \%)$ \\
\hline & 70 and above & $0(0.000 \%)$ & $0(0.00 \%)$ & $0(0.00 \%)$ \\
\hline TOTAL & & $302(76.071 \%)$ & $5(1.259 \%)$ & $397(100 \%)$ \\
\hline
\end{tabular}

Table 8. Crosstabulation of AGE and HBV

\begin{tabular}{|c|c|c|c|}
\hline \multirow[t]{2}{*}{ Age categories } & \multicolumn{2}{|c|}{ HBV Status } & \multirow[b]{2}{*}{ Total } \\
\hline & Negative & Positive & \\
\hline $\begin{array}{c}<=21.00 \\
\%\end{array}$ & $\begin{array}{c}11 \\
2.8 \%\end{array}$ & $\begin{array}{c}3 \\
0.8 \%\end{array}$ & $\begin{array}{c}14 \\
3.5 \%\end{array}$ \\
\hline $\begin{array}{c}22.00-33.00 \\
\%\end{array}$ & $\begin{array}{c}132 \\
33.2 \%\end{array}$ & $\begin{array}{c}20 \\
5.0 \%\end{array}$ & $\begin{array}{c}152 \\
38.3 \%\end{array}$ \\
\hline $\begin{array}{c}34.00-45.00 \\
\%\end{array}$ & $\begin{array}{c}137 \\
34.5 \%\end{array}$ & $\begin{array}{c}20 \\
5.0 \%\end{array}$ & $\begin{array}{c}157 \\
39.5 \%\end{array}$ \\
\hline $\begin{array}{c}46.00-57.00 \\
\%\end{array}$ & $\begin{array}{c}53 \\
13.4 \%\end{array}$ & $\begin{array}{c}2 \\
0.5 \%\end{array}$ & $\begin{array}{c}55 \\
13.9 \%\end{array}$ \\
\hline $\begin{array}{c}58.00-69.00 \\
\%\end{array}$ & $\begin{array}{c}15 \\
3.8 \%\end{array}$ & $\begin{array}{c}1 \\
0.3 \%\end{array}$ & $\begin{array}{c}16 \\
4.0 \%\end{array}$ \\
\hline $\begin{array}{c}70.00+ \\
\%\end{array}$ & $\begin{array}{c}3 \\
0.8 \%\end{array}$ & $\begin{array}{c}0 \\
0.0 \%\end{array}$ & $\begin{array}{c}3 \\
0.8 \%\end{array}$ \\
\hline $\begin{array}{c}\text { Total } \\
\%\end{array}$ & $\begin{array}{c}351 \\
88.4 \%\end{array}$ & $\begin{array}{c}46 \\
11.6 \%\end{array}$ & $\begin{array}{c}397 \\
100.0 \%\end{array}$ \\
\hline
\end{tabular}

Table 9. Crosstabulation of AGE and HCV

\begin{tabular}{|c|c|c|c|}
\hline \multirow[t]{2}{*}{ Age categories } & \multicolumn{2}{|c|}{ HBV Status } & \multirow[b]{2}{*}{ Total } \\
\hline & Negative & Positive & \\
\hline $\begin{array}{c}<=21.00 \\
\%\end{array}$ & $\begin{array}{c}12 \\
3.0 \%\end{array}$ & $\begin{array}{c}2 \\
0.5 \%\end{array}$ & $\begin{array}{c}14 \\
3.5 \%\end{array}$ \\
\hline $\begin{array}{c}22.00-33.00 \\
\%\end{array}$ & $\begin{array}{c}133 \\
33.5 \%\end{array}$ & $\begin{array}{c}19 \\
4.8 \%\end{array}$ & $\begin{array}{c}152 \\
38.3 \%\end{array}$ \\
\hline $\begin{array}{c}34.00-45.00 \\
\%\end{array}$ & $\begin{array}{c}134 \\
33.8 \%\end{array}$ & $\begin{array}{c}23 \\
5.8 \%\end{array}$ & $\begin{array}{c}157 \\
39.5 \%\end{array}$ \\
\hline $\begin{array}{c}46.00-57.00 \\
\%\end{array}$ & $\begin{array}{c}47 \\
11.8 \%\end{array}$ & $\begin{array}{c}8 \\
2.0 \%\end{array}$ & $\begin{array}{c}55 \\
13.9 \%\end{array}$ \\
\hline $\begin{array}{c}58.00-69.00 \\
\%\end{array}$ & $\begin{array}{c}16 \\
4.0 \%\end{array}$ & $\begin{array}{c}0 \\
0.0 \%\end{array}$ & $\begin{array}{c}16 \\
4.0 \%\end{array}$ \\
\hline $\begin{array}{c}70.00+ \\
\%\end{array}$ & $\begin{array}{c}1 \\
0.3 \%\end{array}$ & $\begin{array}{c}2 \\
0.5 \%\end{array}$ & $\begin{array}{c}3 \\
0.8 \%\end{array}$ \\
\hline $\begin{array}{c}\text { Total } \\
\%\end{array}$ & $\begin{array}{c}343 \\
86.4 \%\end{array}$ & $\begin{array}{c}54 \\
13.6 \%\end{array}$ & $\begin{array}{c}397 \\
100.0 \%\end{array}$ \\
\hline
\end{tabular}




\section{RESULT DESCRIPTION}

A total of 397 participants were recruited for this study of which 138(34.8\%) were Male and 259 (65.2\%) were female (Figure 1). Participants were within the age range of 8 to 80 years with age mean of 36.9. Total participants within the age bracket less than or equal to 21 years were 14(3.5), 22-33 years were $152(38.3 \%), 34-45$ years were $157(39.5 \%), 46-57$ years were 55(13.9\%), 58-69 years were 16(4\%) and those who had 70 years and above were $3(0.8 \%)$ (Figure 2). Figure 3 shows the overall HBsAg status of participants 46(11.6\%) of the participants were positive for viral hepatitis B, while in Figure 4., $54(13.6 \%)$ of the entire population under consideration were positive for HCV. Table 1. Is the cross tabulation and chi-square test of association of the two at-risk population (HCWs and PLHIV) and HBV. The number of atrisk population who were positive for $\mathrm{HBV}$ were $46(11.59 \%)$ out of which $9(2.27 \%)$ were HCW and $37(9.32 \%)$ were PLHIV (Table 1.). There was said to be a statistically significant association between at-risk-population and HBV. Table 2. Is the cross tabulation and chi-square test of association of the two at-risk population (HCWs and PLHIV) with HCV. The number of at-risk population who were positive for $\mathrm{HCV}$ were $54(13.6 \%)$ out of which $17(4.28 \%)$ were HCW and 37(9.32\%) were PLHIV (Table 2.). There was no significant association between at-risk population and HCV observed. Table 3 shows the distribution of co-infection $(\mathrm{HBV}+\mathrm{HCV})$ among at risk population results shows that out of $5(1.26 \%)$ at-risk population who were coinfected with the two viruses, $1(0.25 \%)$ occurs among HCWs and 4(1.01) were PLHIV respectively. Table 4 shows the cross tabulation and chi-square test of association of the two at-risk population based on participants' gender and HBV. The result shows that $46(11.59 \%)$ of that participants were positive for HBV out of which 11(2.77\%) were Male and 35(8.82\%) were females. No statistically significant association was observed between gender and HBV infection. Similarly, Table 5 shows the cross tabulation and chi-square test of association of the two at-risk population based on their gender and $\mathrm{HCV}$. The result shows that $54(13.6 \%)$ of that participants were positive for HCV out of which $15(3.78 \%$ ) were Male and 39(9.82\%) were females. There was no statistical association between gender and HCV. There was no test of association conducted between age categories and hepatitis $\mathrm{B}$ and $\mathrm{C}$ viruses because some of the cells had zero entries which violates Chi-square test rules. Table 6. Shows the overall statistics of at-risk population based on gender and Coinfection (HBV+HCV). A total of 5 participants representing $1.26 \%$ were coinfected with viral hepatitis $\mathrm{B}$ and $\mathrm{C}$ out of which $(0(0 \%), 1(0.25 \%))$ were Males and females HCWs while $(0(0 \%), 4(1.01 \%))$ were males and females PLHIV respectively.

In addition, Table 7 shows the marginal distribution of at-riskpopulation based on age categories and coinfection $(\mathrm{HBV}+\mathrm{HCV})$. Among all the participants across age categories, $5(1.26 \%)$ were coinfected with the viruses $(\mathrm{HBV}+\mathrm{HCV})$ out of which none were coinfected within the age brackets of (less than or equal to 21 years, 22-33 years, 46-57 years, 58-69 years and 70+ years), only one $1(0.25 \%)$ within 34-45 years was coinfected among HCWs. Also, $(1(0.25 \%), 1(0.25 \%)$ and $2(0.5 \%))$ of PLHIV within (les than or equal to 21 years, 22-33 years and 46-57 years) were coinfected with both viruses (HBV and HCV). None of the PLHIV within the age range of 46 years to $70+$ years were coinfected with hepatitis B and C (Table 7).

As reported in table 8. The age group between 22-33 and 3445 recorded $20(5 \%)$ each for HBV while the age group of $70+$ recorded $0(0 \%)$ prevalence for $\mathrm{HBV}$. The age group of 34-45 recoded the highest prevalence of $23(5.8 \%)$ for $\mathrm{HCV}$ infection while the age group of 58-69 recorded $0(0 \%)$ followed by $70+$ who recorded $2(0.5 \%)$.

\section{DISCUSSION}

Viral hepatitis has been associated with high mortality and morbidity [10] most especially in resource constrained countries where inadequate health facilities continues to emphasize more on treatment of disease conditions rather than preventive medicine despite the role prevalence survey plays in reducing the burden of this disease and its complication from our society [4].

The findings of this study reported a prevalence of $11.6 \%$ (46/397) of the overall participants to be HBV positive and $13.6 \%$ (54/397) positive to HCV. The prevalence of both infections were high based on the endemicity classification by [11] and [12] for HBV and HCV respectively but wasn't in variance with the National prevalence figure of $10 \%-40 \%$ for HBV and $4.7 \%-20 \%$ for HCV [4]. The high prevalence of both diseases among the population can be attributed to iatrogenic processes they most have experienced [4] and also the endemicity of the diseases in the study region. Despite the higher infectious nature of HBV to HCV [13], infection with $\mathrm{HCV}$ was found to be higher and this can be attributed to the modes of transmission common to the population of study. This finding is in agreement with that of [4] who carried out similar study on HCWs in Bida Niger state of Nigeria and reported $11.3 \%$ for $\mathrm{HBV}$ but was not in agreement with their result of $\mathrm{HCV}(2.4 \%)$. The variation may be due to the variation in regional endemicity of the viruses [14].

Looking at the prevalence genderwise, the result shows that $46(11.59 \%)$ of that participants were positive for HBV out of which $11(2.77 \%)$ were Male while $35(8.82 \%)$ were females. No statistically significant association was observed between gender and HBV infection. This implies that HBV infection is independent of gender. The result of this study also shows that $54(13.6 \%)$ of the participants were positive for HCV out of which $15(3.78 \%)$ were Males and 39(9.82\%) were females and no statistical association was observed between gender and $\mathrm{HCV}$. However, the observed differences in figures and percentages can be attributed to the differences in the gender proportion that constitute the population of the study or the higher proportion of females to males reported to have been 
infected with HIV [15] due to their differences in vulnerability constituted by their anatomical differences [16].

The number of at-risk populations who were positive for HBV were $46(11.59 \%)$ out of which $9(2.27 \%)$ were $\mathrm{HCW}$ and $37(9.32 \%)$ were PLHIV. Statistical analysis revealed that there was said to be a statistically significant association between at-risk-population and HBV. The lower percentage of positivity recorded among health care workers can be attributed to the level of their knowledge and practices towards the virus, post exposure prophylaxis and also can be due to the level of vaccination uptake. On the other hand, the higher percentage reported amongst PLHIV can be attributed to the shared modes of transmission of HIV and HBV (sexual intercourse), vulnerability and untimely recognition of $\mathrm{HBV}$ status due to lack of proper awareness of the disease and its asymptomatic nature. Out of the 397 at-risk population who participated in the study, 54(13.6\%) were positive to HCV out rof which $17(4.28 \%$ ) were HCW and $37(9.32 \%)$ were PLHIV. When the prevalence of $\mathrm{HBV}$ and $\mathrm{HCV}$ among HCWs were observed, there is a higher percentage of $\mathrm{HCV}$ positivity which can be attributed to lack of vaccination for HCV. The high positivity of HCV still observed in PLHIV can still be attributed to their vulnerability, shared mode of transmission as well as iatrogenic experiences. However, statistical findings revealed that there was no significant association between atrisk population and $\mathrm{HCV}$ observed despite the differences observed in the percentages.

Out of 5(1.26\%) at-risk population who were co-infected with the two viruses, $1(0.25 \%)$ occurs among HCWs and 4(1.01) were PLHIV respectively which can be a reflection of the prevalence of Co-infection previously reported in the region of this study by Adda. et al., 2020 other west African countries [15][14]. However, the differences between the two sub-groups can still be attributed to their differences in vulnerability and level exposure as reported by [16]

The age group between 22-33 and 34-45 recorded 20(5\%) each for HBV while the age group of $70+$ recorded $0(0 \%)$ prevalence for HBV. The age group of $34-45$ recoded the highest prevalence of $23(5.8 \%)$ for $\mathrm{HCV}$ infection while the age group of 58-69 recorded $0(0 \%)$ followed by $70+$ who recorded $2(0.5 \%)$. For both infections, the age bracket comprising the youthful and adult age reported the highest prevalence of the infections. This can be attributed to the fact that youths are sexually active group. The lowest case was found to exist among the older population probably due to their lower figure among the general population and work force, the infections were cleared before this age or most of them most have succumb to death due to lack of management and treatment and likely progression to cancer liver related illness as spelt out by [17]. Similar findings were also reported in the work of [18] in their report of seroprevalence of viral hepatitis among the general population in the same region.

\section{CONCLUSION}

The findings of this study reported a high prevalence of viral hepatitis infection amongst the at risk population which is in concordance with the national prevalence. This suggests that the ailment is posing a serious threat to the health care system and the region at large. This calls for the employment of aggressive preventive and elimination measures so as to succeed in achieving the hepatitis free World.

\section{REFERENCES}

[1] Ndako, J. A., Owolabi, A. O., Olisa, J. A., Akinwumi, J. A., Dojumo, V. T., Olatinsu, O. and Adebayo, B. A. (2020). Studies on the prevalence of Hepatitis $\mathrm{C}$ virus infection in diabetic patients attending a tertiary health-care facility South-west Nigeria, BMC Infectious Diseases, 20:664, https://doi.org/10.1186/s12879-020$\underline{05388-7}$

[2] Acikgoz, A., Cimrin, D., Kizildag, S., Esen, N., Balci, P. and Sayiner, A. A. (2020). Hepatitis A, B and C seropositivity among first-year healthcare students in western Turkey: a seroprevalence study, BMC Infectious Diseases, 20:529, https://doi.org/10.1186/s12879-020-05247-5

[3] World Health Organization [WHO](2017). Global Hepatitis Report 2017 Accessed from http://apps.who.int/iris/bitstream/ on $10^{\text {th }}$ June 2020

[4] Amiwero, C. E., Nelson, E. A., Yusuf, M., Olaosebikan, O. F., Adeboye, M. A. N., Adamu, U. G., Oladele, C., Busuyi, J. S., Erinle, S. A., \& Babalola, A. (2017). Knowledge, Awareness and Prevalence of Viral hepatitis Among Health Care workers (HCWs) of the Federal Medical Centre Bida, Nigeria. The Journal of Medical Research; 3(3): 114-120

[5] Emechebe, G. O., Emodi, U., Ikefuna, A. N., Ilechukwu, G. C., Igwe, W. C. et al. (2009). Hepatitis B virus infection in Nigeria- A review, Niger Med J. 50:18- 22

[6] John, O. T., Issa, A. A., Nasiru, Y. and Ozulonye, O. S. (2020). Awareness Level of Hepatitis B and C among Undergraduate Students of Abubakar Tafawa Balewa University (Atbu), Bauchi, International Journal of Research and Innovation in Applied Science (IJRIAS), 5(8):2454-6194.

[7] www.ecdc.europa.eu. Accessed September 2020.

[8] David, K. H., Louise, D., Neil, O. F., Christine, G., Tammy, L., Tara, N. P. et al. (2010). SHEA Guideline for management of Healthcare Workers Who Are Infected with Hepatitis B Virus, Hepatitis C Virus, and / or Human Immunodeficiency Virus, Infection control and Hospital Epidemiology, 31:3

[9] www.cfidtaraba.org

[10] Memon, A. R., Shafique, K., Memon, A., Draz, A. U., Rauf, M. U. A. and Afsar, S. (2012). Hepatitis B and C prevalence among the high risk groups of Pakistani population. A cross sectional study, Public Health, 70-9

[11] WHO (2020). Prevalence of hepatitis virus in the world by country, http://www.who. int/csr/disease/hepatitis/en/, Date accessed online (June, 2020)

[12] Alter, M. J. (2006). Epidemiology of viral hepatitis and HIV coinfection, Journal of Hepatology, 44;S6-S9

[13] Samuel, D., Muller, R. and Alexande, G.(2004). Educational research: National hepatitis B virus programme, Infect. Dis. 234: 221-332

[14] Enitan, S. S., Adebola, O. K., Adejumo, E. N., Itodo, G. E., Ileoma, E., Oluremi, A. S. and Omotola, D. (2019). Prevalence of Hepatitis $\mathrm{B}$ and $\mathrm{C}$ Virus Infection among Students of a Private Tertiary Institution in South-Western Nigeria, 36(3): 1-15

[15] Tremeau-Bravard, A., Ogbukagu, I. C., Ticao, C. J., Abubakar, J. J. (2012). Seroprevalence of hepatitis B and C infection among the HIV-positive population in Abuja, Nigeria. African Health Sciences, 12( 3)

[16] Audu, E. S. (2018). Hepatitis B and C Co-Infections among Patients Accessing Antiretroviral Therapy in a Tertiary Health 
Facility in Lafia, North Central Nigeria, IOSR Journal of Dental and Medical Sciences (IOSR-JDMS), 17(7):65-70

[17] Abbas, S. R. and Zahra, S. (2020). A Review on Natural Compounds for Lung Cancer, Journal of natural sciences, 8; I (2): 47-55.

[18] Adda, K. D., Lamiya, A., and John, O. T.(2020). Seroprevalence of hepatitis $\mathrm{b}$ and or $\mathrm{c}$ viruse (s) among the general population in Jalingo, Taraba State. International Journal of Research in Medical Science.2(1) 23-27. 